\title{
Nettundervisning i matematikk - hva skal til for å lykkes?
}

\author{
P. Andersen, Universitetet i Sørфst-Norge
}

\begin{abstract}
SAMMENDRAG: I mars 2020 måtte hele UH sektoren brått legge om all undervisning fra campusbasert undervisning til undervisning på digitale plattformer på grunn av utbruddet av Covid 19. De fleste lærere valgte å kjøre undervisningen som nettbasert undervisning ved hjelp av Zoom, gjerne i kombinasjon med andre digitale løsninger som f. eks bruk av læringsvideoer. For mange var dette en helt ny måte å jobbe på. Overgangen fra å stå i klasserommet til plutselig å drive nettundervisning fra PC var stor for mange. Med dagens teknologi er det fullt mulig å gjennomføre god og variert undervisning også på nettet. I artikkelen ser vi nærmere på hvordan vi kan utnytte mulighetene som ligger i Zoom og hvordan vi kan bruke ulike verktøy og programmer i kombinasjon med Zoom. Artikkelen fokuserer også på ulike grep vi som lærere kan gjøre ved gjennomføring av undervisningen for at den skal bli best mulig. Eksemplene er i hentet fra matematikkfaget, men mye av det som presenteres har også en overføringsverdi til andre fagområder.
\end{abstract}

\section{BAKGRUNN}

Onlineundervisning er ikke noe nytt i UH sammenheng. Ved daværende Høgskolen i Finnmark, som nå er en del av Norges Arktiske Universitet, brukte vi allerede i 1999 lyd/bilde studio i undervisningen både i allmennlærer- og førskolelærerutdanningen. Lyd/bilde studio ble primært benyttet som supplement til samlingene og fra tid til annen også for å gjennomføre muntlig eksamen. Lyd/bilde studio ble også benyttet ved andre institusjoner i Nord-Norge i samme periode [3].

I 2006 startet de første forsøkene med online nettundervisning ved daværende Høgskolen i Telemark, som nå er en del av Universitetet i Sørøst-Norge (USN). Etter de første forsøkene ble dette formelt introdusert på masterstudiet i kunst og håndverk i 2008 og deretter på allmennlærerutdanningen i 2009. Disse studiene var nettbaserte, men med noen fysiske samlinger i tillegg. Verktøyet som ble brukt var Nefsis og senere Omnijoin. Disse programmene fungerte etter de samme prinsippene som Zoom selv om mulighetene var noe begrenset sammenliknet med Zoom.

Ved USN har vi over 10 års erfaring med online nettundervisning i lærerutdanningene. Gjennom disse årene har vi utviklet og funnet en form på undervisningen som vi mener fungerer bra. Vi var således godt rustet når Covid 19 gjorde at all undervisning måtte legges om til nettundervisning i mars 2020 . Konseptet vi har utviklet på Notodden er et helhetlig konsept som innebærer både online undervisning med Zoom i kombinasjon med samlinger, arbeidskrav, veiledning $\mathrm{mm}$. Alle komponentene er viktig for å få gode helhetlig studier. I denne artikkelen vil jeg imidlertid fokusere på selve online undervisningen og muligheter som ligger der. Boken "Matematikkundervisning i en digital verden" [4] tar for seg nettundervisning i et videre perspektiv enn det som er mulig å gjøre her.

\section{EKSEMPEL PÅ NETTUNDERVISNING}

For studentene er det viktig at de opplever nettundervisning som et tilnærmet fullverdig alternativ til campusundervisning. Med dagens teknologi er det lagt godt til rette for at nettundervisningen kan gjøres både faglig interessant, variert og spennende. I videoen under viser jeg et eksempel på en tenkt online nettforelesning i matematikk der temaet er kombinatorikk for matematikkstudenter i lærerutdanningen. Det må understrekes at dette er en film der formålet er å demonstrere teknikker og pedagogiske prinsipper som jeg legger til grunn for min undervisning. Hadde dette vært en reell forelesning for studentene, ville jeg naturligvis brukt mer tid og forklart ting mer grundig enn det jeg gjør i eksempelet.

Eksempel på forelesning på nett

I videoen bruker jeg flere forskjellige verktøy som PowerPoint, Excel, Pyhton og SMART Notebook som jeg bruker til håndskrift $\mathrm{i}$ kombinasjon med et digitalt skrivebrett. I tillegg demonstrerer jeg også en praktisk aktivitet. Dette viser noen av mulighetene som ligger i nettundervisning. Det er mye annet som er mulig å få til i nettundervisning. Dette er kun noen eksempler og noen ideer til hva som er mulig å få til. 


\section{HVA SKAL TIL FOR Å LYKKES MED NETTUNDERVISNING?}

I dette kapittelet skal jeg se nærmere på hva som skal til for å lykkes med nettundervisning. Videoen i forrige kapittel vil blir brukt som utgangspunkt for diskusjonen. Både forberedelsesfasen og selve gjennomføringen blir gjennomgått og diskutert.

\subsection{Lærerens tekniske kompetanse}

For å drive nettundervisning er det helt nødvendig at lærer har basiskompetanse i Zoom og øvrige verktøy som brukes. Dette er viktig av særlig to grunner. Det ene er at når lærer nødvendig kompetanse i programmet, vil det være mye enklere å håndtere utfordringer som måtte dukke opp underveis i løpet av undervisningsøkten. Dersom læreren må kontakte IT for å få bistand hver gang det dukker opp mindre tekniske utfordringer blir undervisningen veldig oppstykket og studentene kan lett miste fokuset. Det er uheldig og kan gå utover læringsutbytte.

Det andre og kanskje viktigste er at god kompetanse på Zoom bidrar det til at læreren kan senke skuldrene og heller bruke energien på det pedagogiske arbeidet. At lærer kan ha fullt fokus på det pedagogiske arbeidet og slippe å bruke energi på tekniske detaljer bidrar til at kvaliteten på undervisningen også blir bedre. Læreren trenger naturligvis ikke være noe teknisk ekspert på Zoom, men en må ha nødvendig kompetanse til at de pedagogiske mulighetene som ligger i verktøyet kan utnyttes og også kunne håndtere mindre tekniske utfordringer som oppstår.

\subsection{Forberedelser til nettundervisning}

Gode beredelser er viktig for at nettundervisningen skal bli best mulig. Som med annen undervisning må lærer forberede det rent faglige som skal presenteres, men i tillegg må stoffet også forberedes med tanke på at det skal gjøres på nettet og ikke i klasserommet. Det er annerledes å undervise på nett og stoffet må forberedes på en litt annen måte. Samtidig kan en få til veldig mye spennende på nett om en er litt kreativ og gjør gode forberedelser.

Videoen under viser hvordan jeg går frem når en nettforelesning skal forberedes. Jeg prøver å vise både oppsett av rommet og hvordan de ulike programmene som brukes i Zoom settes opp for å få gjennomført en forelesningene. Videoen tar utgangspunkt i eksempelvideoen i kapittel 2 og bør sees i tilknytning til den.

Video som viser hvordan en skal forberede og gjennomføre nettforelesning

Jeg sørger alltid for å være på plass minst en halv time før undervisningen starter for å koble opp nødvendig utstyr, sette opp programmene jeg skal bruke og sjekke alt at fungerer som det skal. Da er det også tid til å få ryddet opp i eventuelle tekniske utfordringer. Når alt er gjort klart i god tid før oppstart kan læreren ta imot studentene på en hyggelig måte og hjelpe dem med eventuelle problemer de måtte ha. Selv om studentene er på nett, setter de pris på lærer tar imot og hilser på dem, og ikke sitter med hode i datamaskinen for å gjøre siste forberedelser.

\subsection{Kommunikasjon med studentene}

Studentene kan kommunisere med lærer i Zoom enten ved å ta ordet muntlig eller ved å skrive spørsmål eller kommentar i chaten. Ofte velger studentene å bruke chaten fremfor å ta ordet muntlig. Når en student sender et spørsmål i chaten forventer de at læreren ser spørsmålet og følger det opp. Erfaringsmessig blir studentene ganske irritert om de ikke får svar på det sender inn. For lærer kan det ofte være en utfordring og ha fokus både på det som skal formidles, samtidig som en skal følge med på om det kommer innspill på chaten. Likevel er det viktig at lærer faktisk klarer å følge opp det som kommer av innspill. Det er også viktig å finne en balanse med å følge opp det som kommer uten at undervisningen blir unødig oppstykket. Vi skal se litt på hvordan dette kan gjøres og hvilke teknikker som kan brukes for å få dette til på en hensiktsmessig måte.

Jeg deler studentens spørsmål og kommentarer inn i 3 kategorier:

Kategori 1. Dette er spørsmål og kommentarer som må følges opp umiddelbart. Det kan være kommentarer som går på at jeg har regnet feil, skrevet av feil oppgave, studentene ser ikke det jeg gjør fordi jeg har glemt å dele etc. Dette må naturligvis tas tak i med en gang og rettes opp. Studentene blir ganske frustrert når lærer bare fortsetter selv om de har påpekt at det f. eks er regnefeil i utregningene. 
Det er derfor viktig å ha et øye på chaten underveis slik at får fanget opp om det kommer innspill som umiddelbart må håndteres.

Kategori 2. Dette er spørsmål og kommentarer som er faglig relevante og som må følges opp, men som ikke er av en slik art at det må tas med engang. Det er ting som typisk kan vente til en er ferdig med resonnementet en holder på med eller med oppgaven/eksemplet som gjennomgås. Et eksempel på dette kan være at en drøfter funksjonen

$$
f(x)=x^{3}-3 x+2
$$

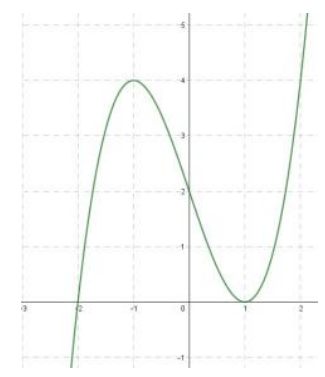

Fig 1. Grafen til $f(x)$

og en student kommenterer på chatten at denne er symmetrisk om punktet $(0,2)$ og spør om alle tredjegradsfunksjoner er symmetriske om vendepunktet. Spørsmålet er faglig interessant og bør følges opp, men det er ikke noe som haster. Slike spørsmål kan følges opp når eksemplet er gjennomgått, men før det neste eksempelet gjennomgås.

Kategori 3. Dette er spørsmål som ikke har noe med selve faglige arbeidet å gjøre. Det kan f. eks være spørsmål om studieveileder er på jobb, om eksamensdato er fastsatt etc. Dette er spørsmål som jeg synes er greit å ta i en pause. Jeg tilkjennegir gjerne underveis at jeg har sett spørsmålet, men at de skal få svar på det i pausen.

Det er krevende å hele tiden ha et øye på chaten samtidig som fagstoffet skal formidles. En metode som jeg ofte bruker, er at jeg legger inn noen små grublepauser underveis i timene. Eksempelvideoen $\mathrm{i}$ kapittel 2 inneholder to slike grublepauser. Først ble studentene bedt om å bruke noen sekunder på å vurdere hva sjansen er for å trekke ut to kløvere og litt senere ba jeg dem bruke et par minutter til å komme med forslag til hvordan vi kan regne på dette. Formålet med de grublepausene er todelt. Det ene er det rent faglige. Grublepausene gir studentene mulighet til å tenke gjennom problemstillingen som er presentert og finne mulige måter å angripe den på. Dette er viktig i seg selv. Det andre er at disse små grublepausene gir lærer et lite pusterom. Da kan lærer i fred og ro gå gjennom chaten og se om det er kommet spørsmål som er oversett og som bør følges opp. Dersom det er ting som bør følges opp, så tar jeg tak i det straks etter grublepausen. I en økt på 45 minutter legger jeg alltid inn minst 2-3 slike små grublepauser. Slike grublepauser er også med på å senke tempoet i undervisningen. Det kommer vi tilbake til i neste kapittel.

I Zoom kan klassen deles inn i grupper som kan sendes ut i breakout rom der de kan diskutere problemstillinger i mindre grupper. Dette er svært nyttig og bidrar både til variasjon i undervisningen og forpliktende deltakelse i diskusjonene. Vi skal ikke gå nærmere inn på det her, men heller vise til en video [7] Kjetil Liestøl Nielsen har laget om hvordan breakout rom kan brukes i undervisningen sammen med studentresponssystem. Samskrivningsverktøy kan også brukes i tilknytning til arbeid i breakout rommene. Dette diskuteres blant annet i en artikkelen fra MNT konferansen i 2019 [8].

\subsection{Tempo og flyt i undervisningen}

En ting som en bør være oppmerksom på når har nettundervisning er tempoet i undervisningen. Det er lett for at lærer ubevisst går fort frem med den konsekvens at studentene ikke henger godt nok med og ikke får det læringsutbytte de bør få. Det er viktig med bevissthet rundt dette. I et fysisk klasserommet er det som oftest ikke noe stort problem da ansiktsuttrykket til studentene gjerne indikerer at de ikke henger med samtidig som de gjerne også sier ifra til læreren. På nettet kan det være en større utfordring. Læreren ser ikke studentene på samme måte og de pleier heller ikke å være like aktive med å ta ordet for å si i fra om dette.

I forrige kapittel var vi innom grublepauser og hvordan de kan brukes for å få en god kommunikasjon med studentene. Grublepausene bidrar i tillegg til dette, også til et litt roligere tempo i undervisningen. 
Grublepausene gjør at studentene får tid til å puste, tenke og reflektere. Er det noe de føler har gått over stokk og stein i undervisningen, så sier de gjerne ifra. Lærer har da mulighet til å justere kursen. Grublepausene gir også lærer tid og rom til å reflektere over hvordan undervisningen har forløpt, og lærer vil dermed kunne gjøre nødvendige korreksjoner om det er nødvendig.

\subsection{Variasjon i undervisningen}

I et vanlig klasserom er det enkelt for lærer å variere undervisningen ved f. eks å veksle mellom bruk av PowerPoint, vanlig tavle, diskusjon i smågrupper, oppgavearbeid mm. Når en underviser på nett er det like viktig at undervisningen blir variert og at læreren er bevisst på dette. En vanlig strategi hos mange er at det blir utarbeidet en PowerPoint til timen som så blir gjennomgått. Dette opplever studentene på nett ofte som monotont og kjedelig selv om det faglige innholdet som presenteres er bra.

I eksempelvideoen i kapittel 2 brukte jeg flere forskjellige verktøy. I tillegg jeg la jeg også inn en praktisk $\varnothing \mathrm{kt}$ for å vise studentene hvordan det er mulig å jobbe med dette i klasserommet med elever. Dette ble gjort først og fremst av faglige årsaker slik at studentene kan få et best mulig utbytte av undervisningen. Samtidig er dette også med på å skape variasjon i undervisningen slik at den ikke blir så monoton for studentene. I Zoom kan en dele nær sagt alle programmer og nettsider så det er fullt mulig å få til en god variasjon. I tillegg kan det i mange sammenhenger også være lurt å bruke breakout rom for å skape diskusjon mellom studentene i grupper. Dette bidrar også til variasjon.

\subsection{Bruk av håndskrift}

I matematikkundervisning foretrekker de fleste lærere å bruke håndskrift når det skal vises utregning f. eks ved gjennomgang av oppgaver og eksempler. Tilbakemeldingene fra studentene er at de føler det er lettere å forstå det som presenteres når lærer kan skrive og forklare samtidig. De blir deltakende i prosessen på en annen måte enn om du kun får presentert utregningene i en PowerPoint. PowerPoint kan være hensiktsmessig å bruke i en del tilfeller som f. eks presentasjon av oppgavetekst, men når oppgaven skal løses er det lettere for studentene å følge lærers tankegang når det brukes håndskrift.

Det finnes heldigvis mange gode alternativer for å håndskrive i Zoom. I videoen i kapittel 2 ble et digitalt skrivebrett brukt i kombinasjon med SMART Notebook. Det finnes mange forskjellige typer skrivebrett på markedet. De kan kjøpes for ca. 800 kroner og oppover. For å gjennomføre nettundervisning klarer en seg godt med et av rimelige brettene.

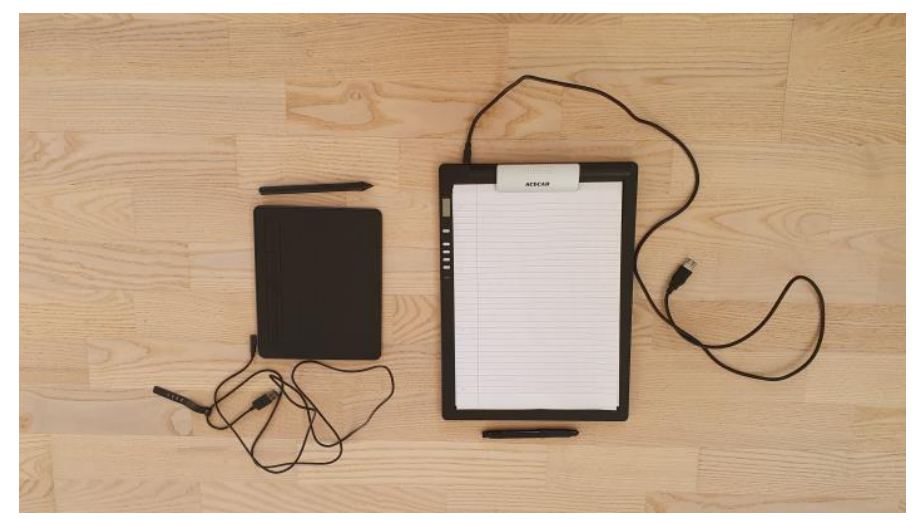

Fig 2. Digitale skrivebrett

Digitale skrivebrett gir flere interessante muligheter i nettundervisningen. Det ene er at det gjør det mulig å skrive for hånd $\mathrm{i}$ selve konferansen, akkurat som på en vanlig tavle. Det finnes et innebygget whiteboard i Zoom som kan brukes, men det er også mulig å bruke tredjeparts programmer som f. eks SMART Notebook som er programvaren til SMART Board. SMART Notebook kan brukes på PC selv om den ikke er koblet til et SMART Board. Fordelen med å bruke SMART Notebook er at også øvrig funksjonaliteten som ligger i programmet kan utnyttes. Programmet gir muligheter til å lage figurer, konstruere med passer og linjal, lage interaktive undervisningsopplegg mm. En kan også enkelt skrive ut notatene etterpå til studentene. En grundig gjennomgang av SMART Notebook finner dere i dette nettkapittelet til QED bøkene [1] og i disse videoene [2]. 


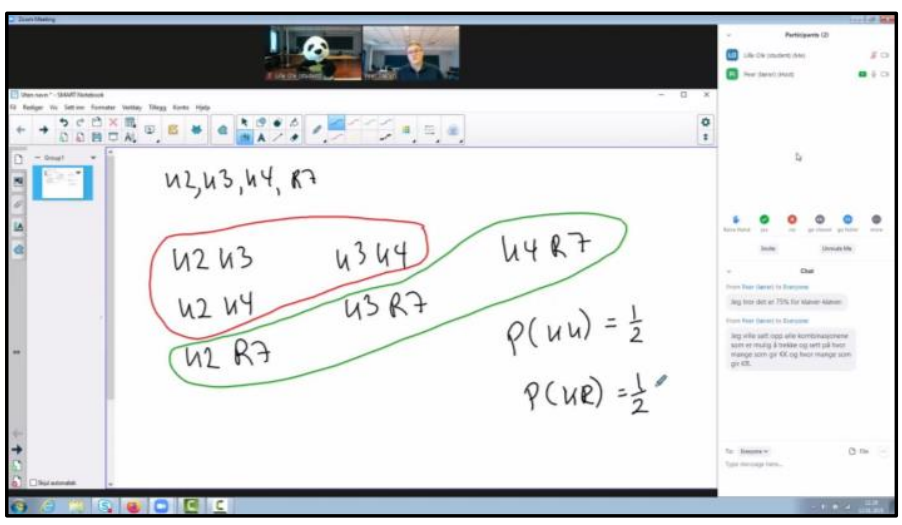

Fig 3. Skjermbilde fra nettforelesningen der SMART Notebook brukes

Det finnes også andre muligheter til å bruke håndskrift i konferansen. En mulighet som mange bruker er å dele Ipad inn i Zoom konferansen. Da logger en seg på i Zoom med Ipad'en og deler whiteboard med den. Det fungerer egentlig veldig greit, særlig om en har en stor Ipad og en Apple pencil. Videoen under viser hvordan Ipad kan brukes for å håndskrive i Zoom.

Video som viser hvordan en Ipad kan brukes til å håndskrive

Det er også mulig å bruke et løst webkamera eller et dokumentkamera og filme når det skrives på et ark. Dette er en løsning som også kan fungere, selv om jeg ikke synes det er helt optimalt. Det er lett for at hånden skygger for det skrives og at skriften heller ikke er i fokus og blir uskarp. Men som en nødløsning om det er behov for å håndskrive og en ikke har andre hjelpemidler så kan det være en god løsning. I lenken under er en video som viser hvordan denne teknikken kan brukes.

Video som viser hvordan en webkamera kan brukes til å håndskrive

Det er også mulig å bruke mobiltelefonen som webkamera og filme når en håndskriver på papir. Kjetil Liestøl Nielsen viser hvordan det kan gjøres i denne videoen [6].

\subsection{Praktiske aktiviteter på Zoom}

I videoen viser jeg et eksempel på en praktisk aktivitet som kan gjennomføres i skolen. Jeg velger der å filme meg selv sammen med et kosedyr når vi utfører dette. Det lar seg enkelt gjøre i Zoom dersom en har et ekstra kamera. Jeg brukte i mitt eksempel et kamera som tidligere har stått på et møterom, men et vanlig webkamera fungerer også greit. I matematikkundervisningen til lærerstudenter er det ofte behov for å demonstrere konkretiseringsmateriell og da kan den teknikken brukes. I andre realfag kan det være aktuelt å filme forsøk fra f. eks fysikk, kjemi eller biologi og det lar seg også greit gjøre med ekstra kamera. At en kan trekke inn slike ting i undervisningen bidrar også til å heve den faglige kvaliteten og til å skape variasjon.

\section{REFERANSER}

[1] Andersen, P. (2016). Interaktive tavler i matematikk. Oslo: Cappelen Damm. Hentet 18. januar fra https://web01.usn.no/ panderse/kompendier/interaktive.pdf

[2] Andersen (2016). Videoer om SMART Notebook. Hentet fra https://web01.usn.no/ panderse/notebook.php

[3] Brekke, M., Germeten. S., Jensen, E. B., Jensen, Ø., Sjøvoll, J.(red) (2017). Desentralisert lærerutdanning i nord. Troms $\emptyset$ : Eureka forlag.

[4] Haara, O. F, Norstein. A (red) (2018). Matematikk i en digital verden. Oslo: Cappelen Damm.

[5] Nielsen, K., L. (2020). Breakoutroom i Zoom. Hentet 15. januar 2021 fra https://youtu.be/Qq1-gKwTyMY

[6] Nielsen, K., L. (2020). Mobil som webkamera. Hentet 15. januar 2021 fra https://youtu.be/P4OF8MAgmNc

[7] Nielsen, K., L. (2019). Bruk av omvendt undervisning i et nettbasert matematikkfag. Konferanseartikkel til MNT konferansen 2019. 